\title{
Creative Art Learning Based On Local Culture: The Transformation of Rumah Gadang Carving become Creative Product
}

\author{
Agusti Efi Marthala \\ Home Economic Education Department \\ Faculty of Tourism and Hospitality \\ UniversitasNegeri Padang \\ gustti@yahoo.co.id
}

\begin{abstract}
Every each individual has creative thinking skill. Sometimes, many people when they want to build creative idea will face problems because of lack of exercising or experience. The sources of creative idea are the result of study and the previous creation, and also from direct observation. In creative art learning postgraduate student in culture and education major in social field, Student College faces the boundaries to build creative idea, even the art that has been live in their each environment could be the source of idea to create something. One of that is Minangkabau tradition culture art. One of the creations of Minangkabu is rumahgadang could be a sources of inspiration to create another creativity products. So through this research rumahgadangbecome concept transformation test and idea to become creative product, is the sculpture transformation or rumahgadang in the diversity of decoration in batik art to become creative product.This research is using development method and using qualitative approachment, survey and experiment method. The result in the field directly in processing, then occur feasibility test that become a creative art learning development model based local culture that make the diversity of rumahgadang carving become creative product, batik art and the diversity of songket fabric. From this research the outcome is to developt creative art, the transformation of Minagkabaucarving becomes product design and batik product that is being rooted in Minangkabauculture is valid.
\end{abstract}

Key Words: Learning, Creative Art, Based, Culture, Transformation, Rumah Gadang Art, Batik Fabric.

\section{INTRODUCTION}

Learn is the based to product the changes related with knowledge, art, attitude and values. Several rapprochements that could be achieve in learning, are: (1) give the direction suitable with expectation to reach the goals, (2) provide knowledge and provide suitable guidance with method, (3) the appropriate time to start teaching and learning process and (4) anticipate the possibility of barriers in study. One of learning materials that could provide the direction and guidance in thinking could build several of creativity results. One of the subjects that purpose to give direction and empowerment of student college creativity is "Creative Art" this is the field of Arts Expertise PPs UNP.

The learning of "Creative Art", the things that purpose to support and stimulation pupils in one good direction and equipping the ability to think to create ideas and skill to create something. By increasing the ability of creative thinking, every individual is expected to be motivated to develop the creativity according to their own wishes. The role of education in learning process could give the examples of appropriate thinking, so student can be motivated to think creatively. The lack of skill to build ideas because of the lack of experiences and practices to searching and growing the creative idea. But, initially the creativity is the ability to actualize identity of individual to form and mix the experiment that could be expressions by themself, nature and others (Moustakis 1978).

UtamiMunandar (1992: 47) give the definition, creativity is "the ability to reflect the fluency, flexibility, and the originality in thinking to collaborate a concept." After that, Utami mention that creativity as the whole personality as the result of interaction with environment. Creativity as emerge process toward the new result into attitude. That is the new result emerge from individual attitude that unique that interaction with others, experiment, and living circumstance.

Therefore, it is necessary to maximum the effort to think creatively and innovatively, accompanied by strong wishes for produce something new creation by supported to be outstanding. The innovation to produce new products that never made before, or produce new products that ever exist before. In art creation comprehension toward art, environment and knowledge could be the idea of sources to create a new creation. One of them is a culture thing that ever live in the middle of Minangkabau society.

Culture art that exist around us could be the source of inspiration to create art creation. One of the beneficial of local art is to alter or to transformed become creative art or new products. In the field of culture and art education, there are subject of "art creative". Syllabus from creative art timetable is "Discussion about creative art, pattern, rapprochement and creative art in teaching to design creative concept as individual with background of art discipline regarding to science, technology and local culture”. (Handbook of Postgraduate Program, State University of Padang 2014). 
In the subject of art creative student college is invited to develop the ability to think to absorb the way of thinking that is more straight to create the purpose that they desired to produce the creative ideas. The mind could be developing to be able or creativity as they expected and that are changed through inspiration. So this paper is the result of research about creative art learning development model based local culture (transformation of rumahgadang become creative product).

This research uses development method, qualitative, survey method and experiment. Development method of 4D, the first rapprochement is not only descriptive, but also analysis, it has done to inventoryingand analysing the diversity of rumahgadang carving that is located in West Sumatera. The finding obtained in the field is processed as a reference to be used as a source of learning development of creative art based local culture is to be the diversity of rumahgadangdecoration into a variety of textile art products that is batik artistic variety.

\section{DISCUSSION}

Creativity is the skill to create something (KBBI, 2001). According to Drevdahl, "Creativity is the skill to actualize and to identity individual integrated form Based on experience and have relation by themself, nature and others" (Drevdahl 1978: 29). Because of that, creativity is the ability of someone to produce the composition, product, or any concept that is the new foundation that previously unknown.

Creativity in every people is different, and it has influenced by knowledge and nature around them, the last experiment, seeing previous events, hearing issues, problematic, could affect psychological symptoms of people to develop mind-set and creativity from that experience, there is a process of creativity that is a person's demands to convey a communicative idea. (Sarjono, 2006). Guilford in Munandar (2009) mention that, the characteristics of creativity are: a. Fluency of thinking (fluency of thinking), b. Flexibility, c. Elaboration (elaboration), they are the ability to develop idea and add or make it detail the things of an object, concept or situation becomes more interesting and d. Originality (originality), is the ability to spark a unique idea or the ability to trigger original ideas.

In the creative arts need the courage to change the old concept into something new (lateral thinking). The mind-set of lateral pattern generally could be interpreted as an attitude or a way to uses the effective mind, but can produce the optimal idea. Through the method of thinking, the memory of human mind-set is leaded to always look for alternatives to open the solutions because lateral thinking regarding to experience, creativity, and humour. The four processes are (lateral thinking, experience, creativity, and humour) have the same base, but, if the comprehension, creativity, and humour, then lateral thinking is a more deliberate process. This thought process is like as definitive as using thought or logical thinking-but in different ways (Bono, 1989; 9).

Furthermore, the creative art is the result of a credible product that has elements of art that fly over and get a place in the market. A creative product could be built from the mature thinking and good in planning. The Fundamental is the ability to develop the ideas and add or make it detail of an object, idea or a situation to produce the product is expected.

In creative art learning, it has begun the deep comprehension about the base of object that want to be created or developed. The creative thinking must supported by base of knowledge and wise policy related trend and market develop. So individually could create something new that could accept in the market. A fatal mistake when want to build creative idea is directly jump into design stage, which should start with surveys and studies of possibilities, to produce factual ideas. Drevdahl (1978: 29) "creativity is the ability of people to produce composition, product, or any ideas that previously never exist."

To make creative art become reality is full of boundaries and sometimes it is really hard, not as easy as to build that idea. The difficulty to make it come true is bordered by the rate of development of science and technology at that time. Creative ideas are merely an abstract thought. The idea will remain abstract until the idea is realized. An idea will give an impact and benefit if the idea is manifested into a real form.

So in Creative Art Learning needs a model and development that can be used as a reference of thinking by learners in developing creative ideas. Joice (2009), Prawiradilaga (2008) and Sardiman (2008) define the learning model as a conceptual framework that is used as a guideline in the context of learning as a process of educator interaction with learners. Winataputra (2001: 13) adds that "learning model as a conceptual framework that describes a systematic procedure in organizing learning experiences to achieve specific learning goals".

Thus, the learning model is a conceptual framework arranged in a logical and systematic order as a guide in conducting a learning activity, Hamruni (2012) states that the learning model has four characteristics, namely 1). Theoretical rational logic 2) The foundation of thinking is based on learning objectives 3) Learning methods that can support the process and learning outcomes. 4) Learning environment that support (approach) learning objectives.

So, in the learning of Creative Art, encourage the process of thinking by providing experiences of ways of developing creative thinking to give build the innovative products. Learners are brought to think systematically to think starting from thinking of ideas, sources of ideas, development concepts, development design and development steps to become a product.

Furthemore, in this study used productive creative learning, Zulkifli (2011) argued that productive creative learning is developed by referring to various learning approaches that are assumed to improve the quality of the process and learning outcomes. Productive creative learning model stimulates students to be able to produce ideas that are very interesting (innovative). 
Therefore, Creativity is directly related to productivity and is an essential part in problem solving, Productivity will increase along with increased creativity, and then the thing that needs to be transacted first is to increase creativity. Wankat and Oreovoc (1995) increase creativity can be done by: 1) tell student to be creative, 2) teach student some creativity method and 3) accept the result of creative exercise (Wena, 2012).

Therefore, in learning need to choose a learning model that makes learners are not afraid to learn, develop skills and talents, and develop interest. So the campus becomes the center of intellectual activity, the art of increasing the variety of creativity. Various illustrations of development can be a reference for learners to start thinking and find the source of ideas, create ideas and make it into creative product. Learners do not get inspiration or ideas to be developed, because around the life of each of the many that can be the source of ideas, among which is a cultural tradition that lives in the middle of society. One example, for the people of West Sumatra who has a Minangkabau cultural background, has a variety of traditional objects one of which is a rumahgadang.

RumahGadang is a traditional house of Minangkabau people. RumahGadang serves as a residence and place of traditional ceremonies. RumahGadang is the symbol of existence of a tribe led by a penghulu(leader). The concept of the emblem in the rumahgadangis found in the architectural of the rumahgadang, through the construction and parts of the house or through the carvings which are the rumahgadangdecoration. In a traditional ceremony rumahgadang is very important. If people no longer own a rumahgadangbecause it is extinct, to launch a traditional ceremony, then borrowed a rumahgadangthat is still in the nagari. Rapoport (1983) has conducted research, based on the relationship between the shape of architect and culture. There are several factors that affect each other.

Viewed from the aspect of environmental culture where the rumahgadangis located, the rumahgadangis a physical construction of spatial arrangement, time, communication and its meaning (Rapoport, 1983). The above opinion is underpinned by Waterson (1991), which emphasizes the shape of the house and the relationship with its supporting culture. The house represents and communicates the cultural identity of residents in two ways through representative symbols and through the layout of the house or commonly called the home building environment.

RumahGadang is usually decorated byMinangkabau carving. Almost all motifs are flora and geometric shapes or geometrically arranged flora. The alleged creature can hardly be said to be absent in the motive, but its naming uses the name of animate beings, among them; motif badamudiak (small fish mudik), tantadubaririk (caterpillar march), tantadumaisokbungo (caterpillar sucking flowers) and squirrels bagaluik (squirrel wrestling). All the names of these motifs are only shaped lines, geometric shapes and arches and variative by floral motifs. Engraving is generally present on the walls and panel boards on the outside of the gadang home wall. The inside is not carved, if carved only in certain places only, such as doors and windows along with ventilation.

Making motif carving into batik motif is the transformation of material from wood media into cloth or textile. This change will obviously change the technique from sculpting to altering with canting technique and in fabric weaving adapted to weave technique. This change clearly requires the adjustment of motives and layout by making innovations on the motive but retaining the Minangkabau character.

Batik art is part of the cultural art that was born in the midst of cultural society and is a fusion of technology and art. Batik has a valuable cultural traditions of the archipelago. Kriya batik has been able to elevate the nation's cultural status to the arena of textile world competition in foreign countries, due to ethnic and technical qualities, and various uniqueness.

Affendi added, batik is a cultural art that contains the values of community philosophy, which is a blend of religious concepts, beliefs and culture. Affendi said, studying batik culture in terms of custom symbolism four approaches: a) Colorsimolism (color and technology aesthetic approach), b) symbolism of various patterns (including patterns) including myths (mythic and philosophical adaptation approach), c) (a technology approach of comfort and aesthetics of fabric) and d) the symbolism of batik kaian (sociological approach of anthropology of power and custom), (Affendi, 2006). Affendi's opinion was supported by Djelantik (1999) who said, "batik art is included in the field of aesthetics, both philosophy and scientific".

Therefore, the creation of batik artwork rooted in Minangkabau culture is inseparable from the concept of "adatbersedisyarakat, syarakbersendikitabullah", so that the resulting batik is a splash of cultural art that raises the image of Minangkabau art but is expected to compete in the art of textiles in the global era.

In designing motifs carving into batik motifs need adjustment-shape adjustment. Media that is used for batik carving is much different, the wood carving used is wood while in batik media used is mori (textile for batik), and therefore the motive of carving need to be stilir and adjusted with batik motif with the following steps with 4D: Stage 1 (define), in the step of defining is the stage to describe main materials become arrangement concepts and to know the concept that must be explained to the handicraft maker. In this stage is started with analysis development needed. After analysing the newly described indicators, and inventory of decorative Minangkabau motifs as a source of product development and model development.Stage II Design, design stage is meant here is to design the development of creative arts learner model sourced from local culture Minangkabau, batik motif developed sourced on Minangkabau carving motif. The four steps to be taken at this stage are: 1) the preparation of the test standard (criterion-test construction), 2) the media selection which is in accordance with the material characteristics and learning objectives, 3) the format selection, review existing resource formats and specify the format of instructional materials to be developed, 4) create an initial design according to the selected format. The steps are as follows:Stage III Develop, the next stage 
of development is the stage to produce batik development products that are done through two steps, namely: 1) expert appraisal followed by revision, 2) developmental testing. The purpose of this development stage is to produce the final form of learning devices after revision based on input from expert experts / practitioners and test results data. Steps taken at this stage are as follows: 1) Expert / practitioner validation (expert appraisal), and 2) Developmental testing.Stage IV: Disseminate (Spreading), the process of dissemination is a final stage of development. The dissemination stage is carried out to promote the development product in order to be accepted by the user of the model (learning and product (consumer) Dissemination is done in another class with the aim to know the effectiveness of the use of the device in the learning process Spread can also be done through a transmission process to the related learning practitioners in a specific forum for the purpose of this dissemination get feedback, corrections, suggestions, assessments, to make perfect the final product of development to be ready for adoption by curriculum users.

Product development is done by step product development steps as follows: 1) Product Development begins by analyzing the motive that is used as the source of ideas on the engraving is parsed one by one and analyzed the shape and character. 2) Drawing in accordance with the original carving motifs, motifs drawn on the sides and sorted out which have the same or interrelated characters and philosophies. 3) Decompose motifs into specific parts in order to be rearranged into new motifs with new ideas and views. 4) Motifs changed according to desired design, changes made by not eliminating the character that became the hallmark of the design. Development of motif also in with arrangement of batik motif and layout on clothes. At this stage the motive test and the suitability of motifs on clothing. 5) Appropriate design shapes and layouts are added with isenisen. In this creative work as isen-isen filler used motif weaving Minangkabau'sSongketor form of salur and small flowers commonly found in Minangkabau carving. Those can be seen from Fig. 1, 2, and 3 below.
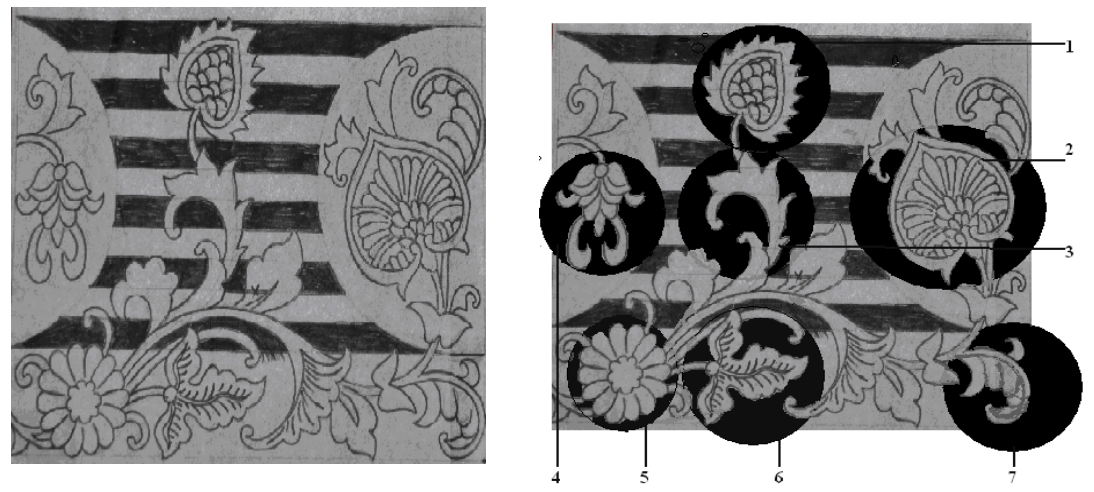

\author{
The sources \\ of Motifs Development: \\ 1. Buah Pinang-pinangmotif \\ 2. SiriahGadangmotif \\ 3. KaluakPakumotif \\ 4. BungoPitulomotif \\ 6. DaunPariomotif \\ 7. KaluakPakumotif
}

Fig. 1. Innovation Batik motif design Minangkabau carved,
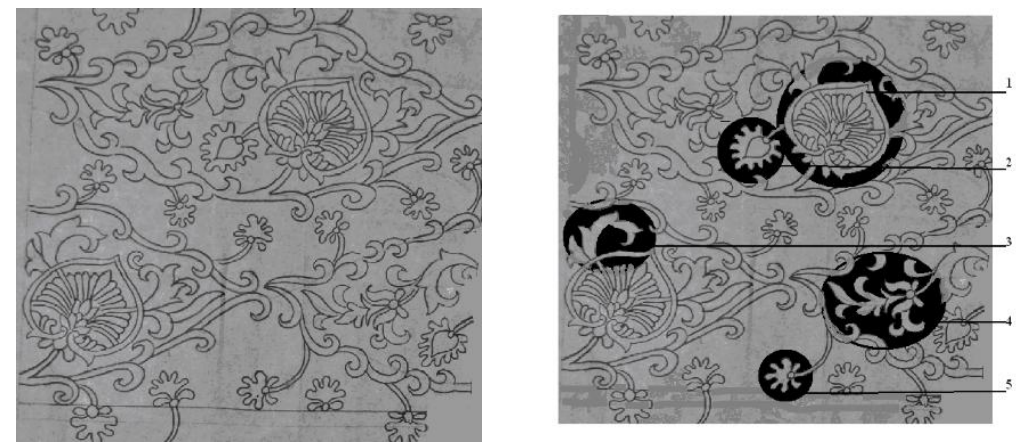

The development of batik motif

1. Siriahgadangmotif

2. pinang-pin fruit motif

3. kaluakpakumotif

4. bungopitulo motif

5. bungogambiamotif

Fig. 2. Batik Motif Design From Carved Motif Minangkabau 

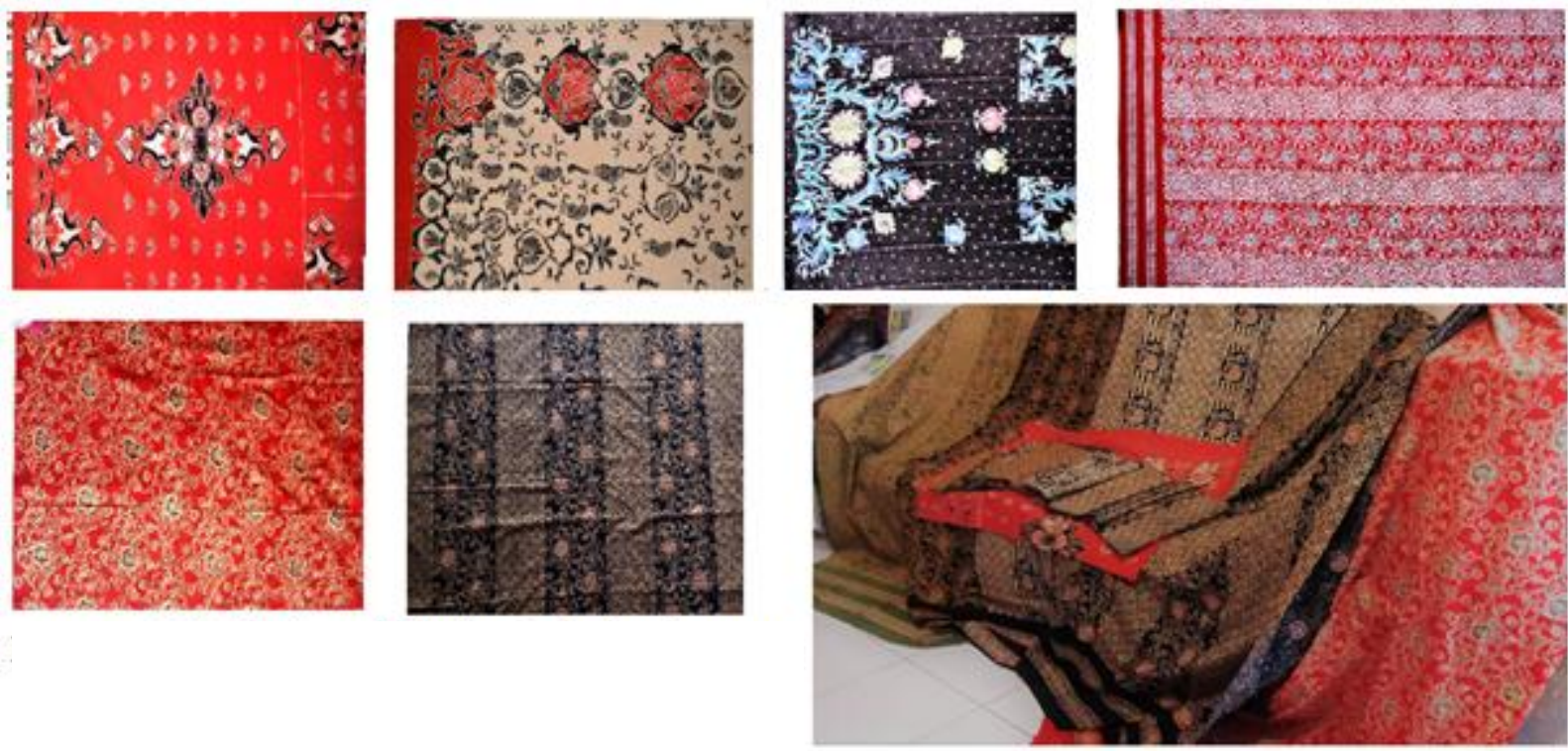

Fig. 3. This Batik Motif Design is the Development of Carved Motif as the Main Motif is Motif Rumah Gadang.

Trial of batik design done with various forms and composition by combining several motifs that are the same or almost the same character and philosophy and motive. Motif stilired and arranged into batik design that is feasible to be applied.

To see the feasibility of the product is tested the validity of the suitability of the design with the technique performed batik test by performing the steps. batik start from designing, move design on mori and batik until goes down. The product result is then FGD. Present at FDD batik experts, lecturers from UNP and ISI Padang Panjang. From the FGD collected suggestions for improvement and refinement of the product. As a market test conducted exhibition, from the exhibition looks enthusiastic visitors to the work of batik on display.

Below are the feasibility test steps the product of batik art innovationtransformation from Minangkabaucarving.

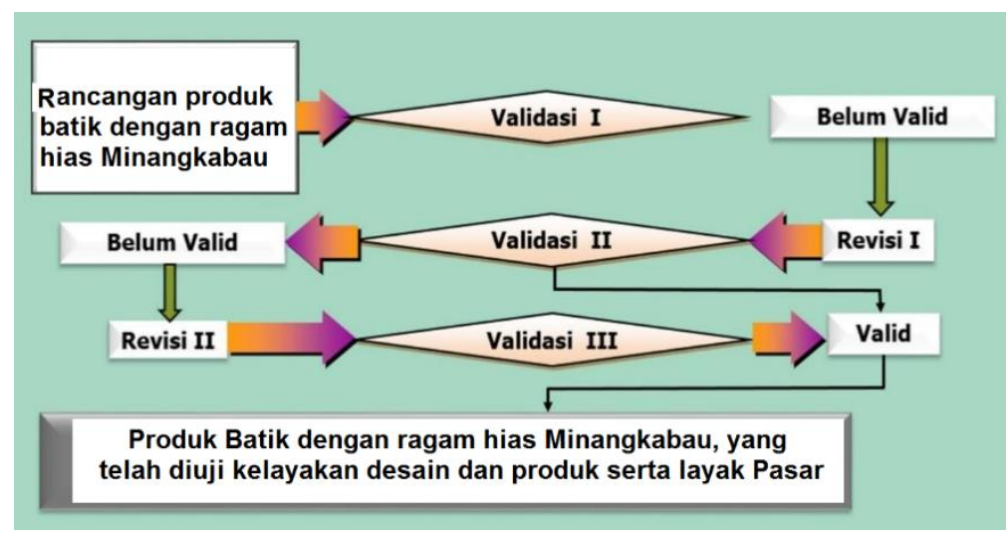

Fig. 4. The Validity of Batik Development by Minangkabau Carving Decoration Variety

\section{CONCLUSION}

Creative art is one of the subjects in the field of art expertise of IPS UNP master program. Utilizing cultural traditions and objects that exist around everyday life can be a source of inspiration in creating creative products. One of them is utilizing local culture by innovating into creative products.

From the research that has been done in the course of creative arts students are invited to develop the ability to think creatively and develop the power of thinking in creating or developing new innovations in accordance with the desired each into a creative 
product. As a development test carried out the development of ideas with the transformation of Minangkabau ornamental customs called rumahgadanginto a variety of ornamental batik art.

For the feasibility of the product has done the market through the exhibition and FGD with students, craft art experts from the State University of Padang, Institute of Art Padang Panjang curator and cultural. The result is a variety of decorative Minangkabau carving is very feasible to be developed into product design and batik products (design and product photos attached).

AAM Djelantik, (1999). Estetika Sebuah Pengantar, Bandung: MSPI

Affendi, Y. (2000). "Seni Kriya Batik Dalam Tradisi Baru Menghadapi Arus Budaya Global”. JurnalSeniRupa Dan Desain Vol 1,1, Agustus. 2000, PusatPenelitian Dan PengembanganMasyarakat (P3M) STSIR Dan Desain Indonesia (STISI).

Clark, Moustakas. (1994). Phenomenological Research Methods, California: SAGE Publication. Inc.

Edward De Bono. (1989). Berfikr lateral. Jakarta:Erlangga

Fraser, Silvia. (1992). Handwoven textiles of south east asia. Singapure: Oxford University.

Hamruni. (2012). Strategi Pembelajaran. Yogyakarta: InsanMadani.

Hamzuri. (1994). Batik klasik. Jakarta: jambatan.

Haurens, Laugewis. (1964). Decorative art in Indonesia textiles. Amsterdam: NV. Mounton \& Co Den Hag.

Hurlock, Elizabeth B. (1978). PerkembanganAnak (Child Development, Sixth Edition) Jilid 2. Jakarta :Erlangga

Ibenzani Usman. (1985). Seni Ukir Tradisional Pada Rumah Adat Minangkabau: Teknik, Pola Dan Fungsi. Tesis ITB.

Joice, Bruce, M.E. (2009). Model of Teaching, Model-model Pengajaran, terjemahan, Edisi Delapan, Yogyakarta: PustakaPelajar.

Kushardjanti. (2002). Batik Klasik Jokyakarta di Daerah Istimewa Yoyakarta Sebuah Kajian Mengenai Bentuk, Fungsi dan Makna. Tesis Universitas Udayana Denpasar.

Made Wena. (2012).Strategi Pembelajaran Inovatif Kontemporer. Jakarta: Bumi Aksara Kecamatan Lela Kabupaten Sikka Propinsi Nusa Tenggara Timu. Jurnal Holistik, Tahun VIII No. 16 / Juli -Desember 2015

Nian S. Jumena. (1990). Batik dan Mitra. Jakarta: Jambatan.

Pasca UNP. (2014). Panduan Penulisan Tesis Pascasarjana. UniversitasNegeri Padang

Peggy R. \& Suwati Kartiwa. (1984). Cloth and Costom In West The Codifilcation of Minangkabau World View. dalam Expedition, the University Museum Magazine of Archeaeology/Antropologi University of Pennsylvania. Vol 26, Number 4, 1984.

Peggy R. \& Suwati Kartiwa. (1984). Cloth and Costom In West The Codifilcation of Minangkabau World View. dalam Expedition, the University Museum Magazine of Archeaeology University of Pennsylvania. Volume 26, Mumber 4, 1984.

Prawiradilaga, Dewi Salma. (2008). Prinsip Disain Pembelajaran. Penerbit: UNP. Padang

Rapoport, Amos. (1983). Housing in Transition, New York: , CBS College

Sardiman. (2008). Interaksi dan Motivasi Belajar Mengajar. Jakarta: PT Raja Grafindo Persada

Udin Winataputra S. (2001). Model-Model Pembelajaran Inovatif, Jakarta: Depdiknas

Utami Mumandar. (1992). Mengembangkan Bakat dan Kreativitas Anak Sekolah: Penuntun Bagi Para Guru Dan Orang Tua. Jakarta: Grasindo

Waterson, R. (1991). The living house: An Antropology of Architecture in South east Asia. Singapure: Oxford University Press Zulkifli. (2011). Pembelajaran Kreatif Produktif. Jakarta: PT Bumi Aksara. 